

\section{METRIC CONVERSION FACTORS}

Multiply

foot (ft)

cubic yard $\left(\mathrm{yd}^{3}\right)$

mile (mi)

square mile $\left(\mathrm{mi}^{2}\right)$

cubic foot per second $\left(\mathrm{ft}^{3} / \mathrm{sec}\right)$
By

0.3048

0.7646

1.609

2.590

.02832
To obtain

meter $(\mathrm{m})$

cubic meter $\left(\mathrm{m}^{3}\right)$

kilometer $(\mathrm{km})$

square kilometer $\left(\mathrm{km}^{2}\right)$

Cubic meter per second $\left(\mathrm{m}^{3} / \mathrm{s}\right)$

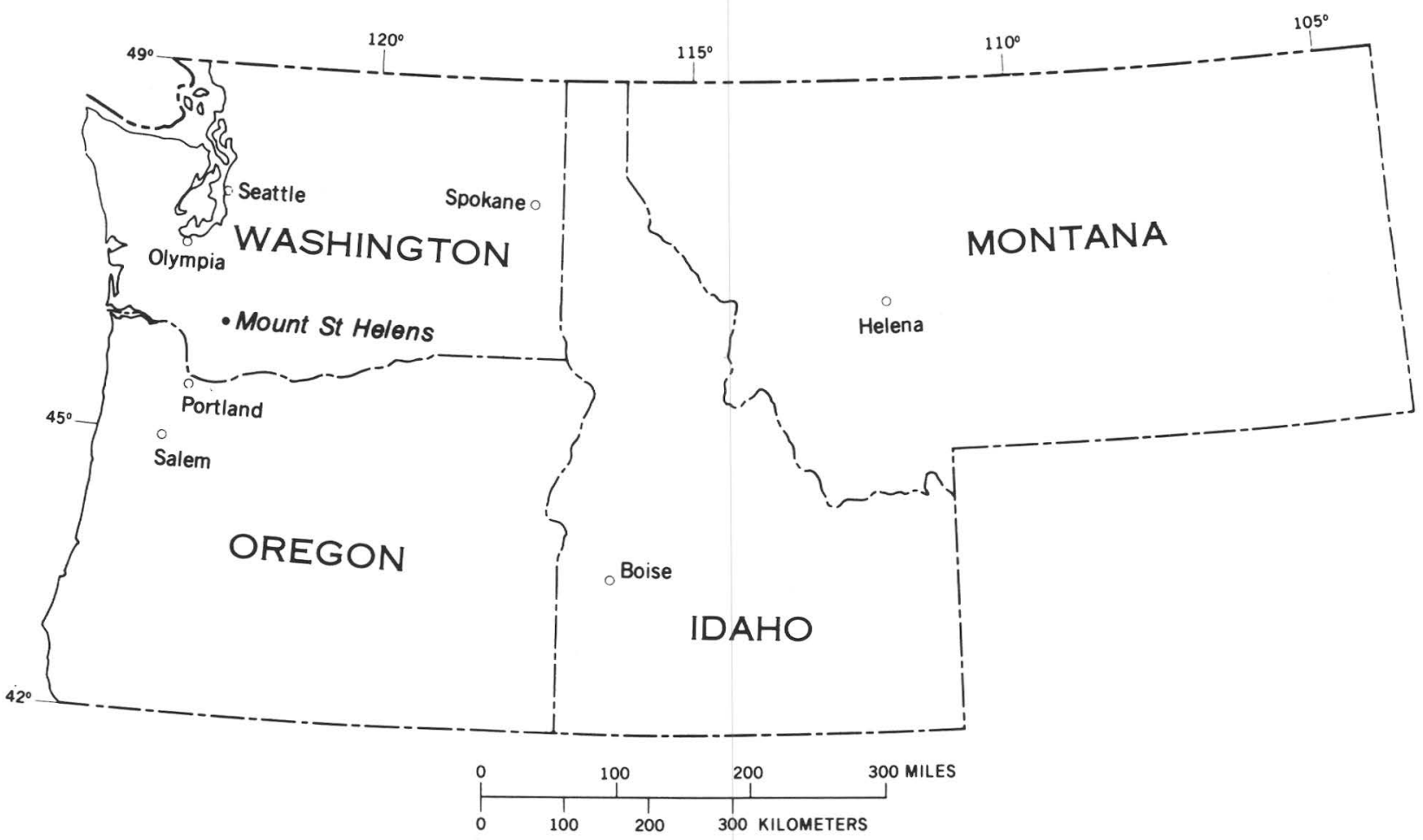

COVER: North Fork Toutle River, June 30, 1980. Volcanic mud flow breccia and debris from the May 18, 1980 eruption of Mount St. Helens (in upper right) are as much as several hundred feet thick in the reach shown. Photograph by Austin Post, U.S. Geological Survey. 


\section{Toxicity of Mount St. Helens Ash Leachate to a Blue-Green Alga}

By Diane M. McKnight, Gerald L. Feder, and Eric A. Stiles

Hydrologic Effects of the Eruptions

of Mount St. Helens, Washington, 1980

GEOLOGICAL SURVEY CIRCULAR 850-F 


\section{United States Department of the Interior}

JAMES G. WATT, Secretary

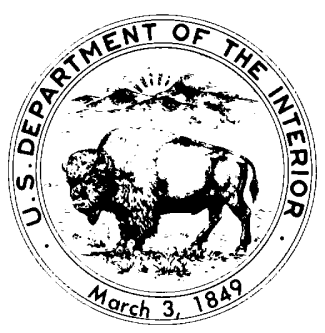

\section{Geological Survey}

Doyle G. Frederick, Acting Director

Library of Congress catalog-card No. 81-600058

Free on application to Distribution Branch, Text Products Section, U. S. Geological Survey, 604 South Pickett Street, Alexandria, VA 22304 


\section{FOREWORD}

On May 18, 1980, after more than a month of earthquakes and eruptions, Mount St. Helens, in southwestern Washington, exploded in a volcanic eruption more violent than any in the conterminous United States during the 20th century. A lateral blast of hot gas and rock particles devastated an area of about 150 square miles on the northern side of the mountain knocking down trees to a distance of 15 miles. Several minutes later, a giant ash cloud rose to about 60,000 feet. Winds then carried the ash cloud across the United States, with heavy fallout and deposition in eastern Washington and parts of Idaho and Montana. Earlier, smaller eruptions deposited ash in western Washington and parts of Oregon and Canada.

The hydrologic effects of the May 18 eruption have been both widespread and intense. During the eruption, a massive debris avalanche moved down the north flank of the volcano depositing about 3 billion cubic yards of rock, ice, and other materials in the upper 17 miles of the North Fork Toutle River valley. The debris deposits are about 600 feet thick in the upper reaches of the valley. Following the avalanche, runoff from the melted glaciers and snow, and possible outflow from Spirit Lake, caused an extraordinary mudflow in the North Fork Toutle River. The mudflow shattered and uprooted thousands of trees, destroyed most of the local bridges, and deposited an estimated 25,000 acre-feet of sediment in the Cowlitz River channel. A considerable amount of additional sediment was conveyed through the lower Cowlitz into the Columbia River where it deposited and formed a shoal that blocked the shipping channel. Mudflows also occurred in the South Fork Toutle River and in tributaries on the east flank of Mount St. Helens which enter Swift Reservoir.

As part of a concerted Geological Survey effort to study the volcanic event and to identify potential hazards, Survey hydrologists have mounted an intensive program to document the hydrologic effects of the eruptions. The major initial hydrologic findings are reported in this circular series. Quick, useful assessment was made possible only because the Survey has long conducted extensive waterresources investigations in the affected areas of Washington, Oregon, and Idaho. Hence, there was a well-defined basis for identification and documentation of the types and magnitudes of hydrologic changes.

The Geological Survey Circular 850, "Hydrologic Effects of the Eruptions of Mount St. Helens, Washington, 1980," consists of individually published short chapters that emphasize data collection activities, field observations, and initial comparisons of pre- and post-eruption conditions. The series will cover hydrologic events occurring on May 18 in the Toutle and Cowlitz River; physical alteration of the Toutle River system; the chemical and physical quality of precipitation, streams, and lakes affected by volcanic ash fall; ash-leaching studies; and Mount St. Helens glaciers.

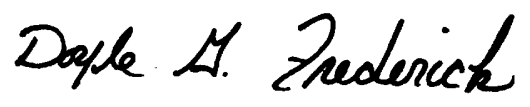

Doyle G. Frederick

Acting Director 


\section{CONTENTS}

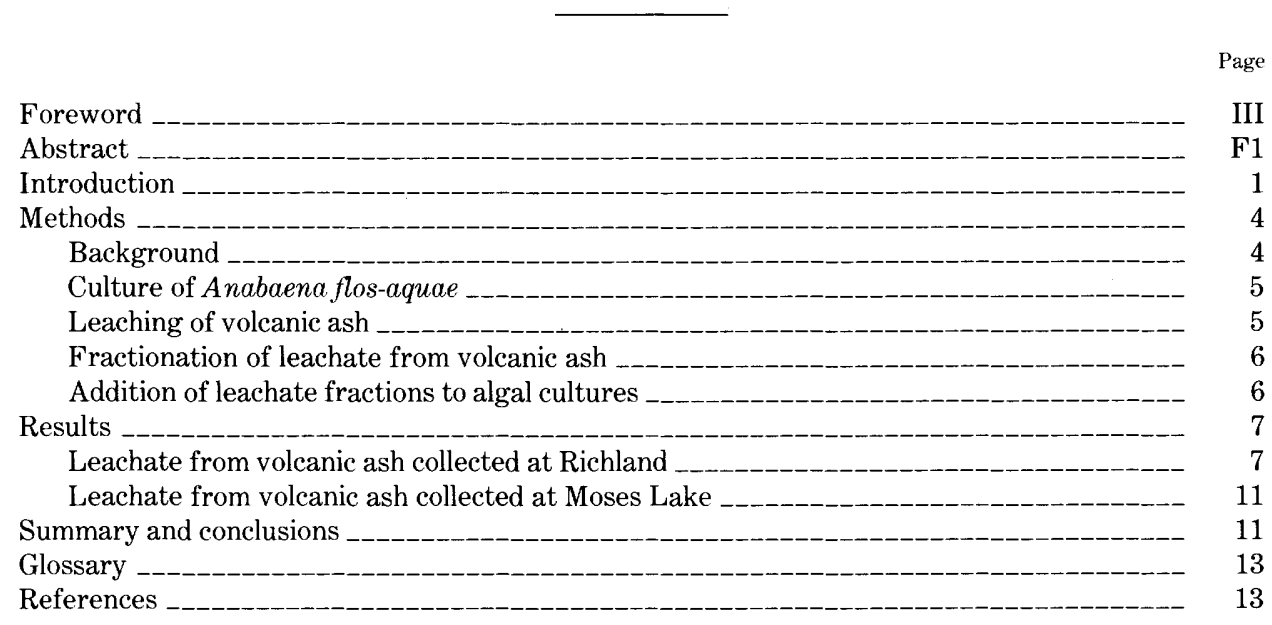

\section{ILLUSTRATIONS}

Page

FiguRE 1. Map showing thickness of ash deposited from the May 18, 1980, eruption of Mount St. Helens

2. Generalized flow chart showing experimental design used to determine the general character of toxicants in leachate from volcanic ash

3. Graph showing idealized growth curve for micro-organisms

4. Graph showing growth of Anabaena flos-aquae exposed to different fractions of leachate from volcanic ash collected at Richland

5. Photomicrographs showing morphological differences between Anabaena flosaquae grown in cultures exposed to various concentrations of unfractionated leachate from volcanic ash collected at Richland

6. Graph showing growth of Anabaena flos-aquae exposed to different fractions of leachate from volcanic ash collected at Moses Lake

\section{TABLES}

TABLE 1. Selected constituents and physical properties of water from (1) four lakes in ash fall area, central Washington; (2) synthetic freshwater; and (3) leachate from Mount St. Helens volcanic ash collected at Richland and Moses Lake, Wash _-

2. Dissolved constituents in leachate from volcanic ash after passing through cationexchange resin column

3. Concentration of dissolved organic carbon and trace metals in cultures used for bioassay experiments with Anabaena flos-aquae

4. Growth rates of duplicate Anabaena flos-aquae cultures exposed to different fractions of leachates from volcanic ash 


\title{
TOXICITY OF MOUNT ST. HELENS ASH LEACHATE TO A BLUE-GREEN ALGA
}

\author{
By Diane M. McKnight, Gerald L. Feder, and Eric A. Stiles
}

\begin{abstract}
This report describes laboratory studies with volcanic ash intended to aid the assessment of the possible effects of ash presence on the blue-green algal populations in lakes. Bioassays using leachate from volcanic ash of the May 18, 1980, eruption of Mount St. Helens, Wash., indicate that leachate derived from ash collected at Richland, Washington, is toxic to the blue-green alga Anabaena flos-aquae, whereas leachate from ash collected at Moses Lake, Wash., is not. The difference in the toxicity of the two leachates may be attributable to differences in concentration of cationic-exchangeable, dissolved, organic compounds. Seventeen percent of the dissolved organic carbon from the leachate from ash collected at Richland was retained on a cationexchange column, whereas only six percent of the dissolved organic carbon from the leachate from ash collected at Moses Lake was retained. Anabaena flos-aquae cultures spiked with dilutions as large as 1 to 250 of leachate derived from volcanic ash collected at Richland showed toxic effects, whereas cultures spiked with a 1 to 25 dilution of leachate derived from ash collected at Moses Lake showed no toxic effects.

The toxic components of the volcanic ash are nonuniformly distributed over the ash fall area. Preliminary data indicate that the toxic components may belong to one or more of the following classes of substances: (1) cationic organic compounds such as amines; (2) highly hydrophobic (sparingly soluble) organic compounds such as phenols that interact with and are retained by the cation-exchange-resin matrix; or (3) metal-organic complexes that are retained by interaction of the metal with the cation-exchange resin.
\end{abstract}

\section{INTRODUCTION}

The May 18, 1980, eruption of Mount St. Helens volcano in Southwestern Washington covered large areas of Washington, Idaho, and Montana with volcanic ash with accumulation of more than $50 \mathrm{~mm}$ in parts of central Washington (fig. 1). To ascertain the possible effects of the ash on water quality, ash samples were collected from several locations for chemical analysis of their distilled water leachates. The results indicate that, relative to natural surface waters in the affected area, the leachates contain high concentrations of several potentially toxic trace elements, specifically manganese $(\mathrm{Mn})$, zinc $(\mathrm{Zn})$, copper $(\mathrm{Cu})$, and cadmium (Cd) (table 1).

In addition, the leachates contain large concentrations of important algal nutrients (phosphate, nitrate, ammonia) and as much as 200 milligrams of dissolved organic carbon per liter $(\mathrm{mgC} / \mathrm{L})$ (Taylor and Lichte, 1980). Chemical analyses of the organic compounds in volcanic ash collected at Richland, Washington, indicate that many of the identified components (for example, dicardoxylic acids, n-alkanes, 4-methaxybenzaldehyde, and trimethylphenanthrene) could have originated as breakdown products of pyrolized plant material (Pereira and others, 1980). These organic products may have formed during the eruption as a lateral blast of superheated gases and hot ash flattened about 40 square kilometers of coniferous forest. J. A. Leenheer (oral communication, 1980) of the U.S. Geological Survey reported that the concentration of organic compounds in leachate from ash varied with location, with higher concentrations near the periphery of the ash fall area than toward its center. In this context, Richland, Wash., is on the southern edge of the ash fall about 140 miles east of Mount St. Helens (fig. 1).

Because of the large concentrations of trace elements and dissolved organic compounds in the leachates, concern arose over the possible effects of the ash on aquatic ecosystems, particularly in the many lakes of the area. Therefore, a preliminary bioassay experiment was conducted using volcanic ash leached with a synthetic solution simulating natural lake water. The organism selected for the test was Anabaena flos-aquae, a common blue-green algae known to be sensitive to trace metals (McKnight and Morel, 1980). Results showed that leachate from volcanic ash collected in 


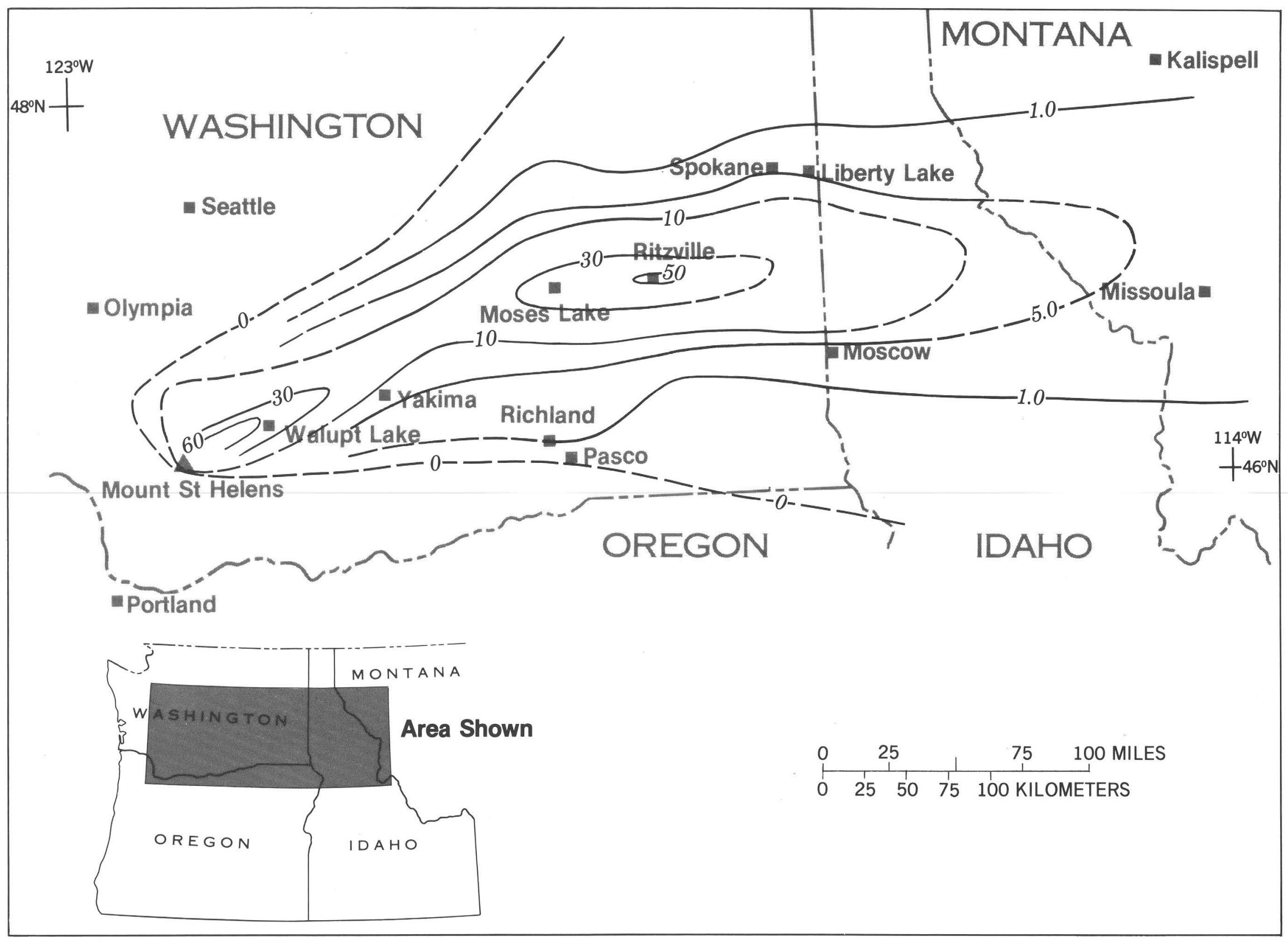

Figuke 1. Thickness of ash deposited from the May 18, 1980, eruption of Mount St. Helens, shown by lines of equal uncompacted thickness, in millimeters. (Adopted from Sarna-Wojicki and others, 1980. Areal distribution, thickness, and volume of downwind ash from the May 18, 1980, eruption of Mount St. Helens, U.S.G.S. Open File Report No. 80-1078.) 
TABLE 1. - Selected constituents and physical properties of water from (1) four lakes in ash fall area, Central Washington; (2) synthetic freshwater; and (3) leachate from Mount St. St. Helens volcanic ash collected at Richland and Moses Lake, Washington.

[NA, not added; ND, not determined]

\begin{tabular}{|c|c|c|c|c|c|c|c|c|c|}
\hline \multirow[b]{3}{*}{ Major cations } & \multicolumn{4}{|c|}{ Lake } & \multirow{3}{*}{$\begin{array}{c}\begin{array}{c}\text { Synthetic } \\
\text { freshwater }\end{array} \\
\mathrm{mg} / \mathrm{L}\end{array}$} & \multicolumn{4}{|c|}{ Mount St. Helens volcanic ash collected at } \\
\hline & \multirow{2}{*}{$\begin{array}{l}\text { Walupt } \\
\mathrm{mg} / \mathrm{L}\end{array}$} & \multirow{2}{*}{$\frac{\text { Warden }}{\mathrm{mg} / \mathrm{L}}$} & \multirow{2}{*}{$\begin{array}{l}\text { Moses } \\
\mathrm{mg} / \mathrm{L}\end{array}$} & \multirow{2}{*}{$\begin{array}{l}\text { Lenore } \\
\mathrm{mg} / \mathrm{L}\end{array}$} & & \multicolumn{2}{|c|}{ Richland } & \multicolumn{2}{|c|}{ Moses Lake } \\
\hline & & & & & & $\begin{array}{c}\text { Concentration } \\
\text { in leachate } \\
\mathrm{mg} / \mathrm{L}\end{array}$ & $\begin{array}{c}\text { Amount leached } \\
\text { per gram ash } \\
\text { mg/g }\end{array}$ & $\begin{array}{c}\text { Concentration } \\
\text { in leachate } \\
\mathrm{mg} / \mathrm{L}\end{array}$ & $\begin{array}{c}\text { Amount leached } \\
\text { per yram ash } \\
\text { mg/g }\end{array}$ \\
\hline $\mathrm{Na}$ & 1.11 & 29 & 11 & 200 & 30 & 167 & 0.17 & 251 & 0.19 \\
\hline $\mathrm{Ca}$ & 1.6 & 6.3 & 12 & 2.9 & 13 & 182 & .21 & 234 & .19 \\
\hline $\mathrm{Mg}$ & .2 & 9.4 & 6.6 & 5.3 & 5 & 39 & .043 & 48 & . \\
\hline $\mathrm{Sr}$ & .009 & .07 & .09 & .02 & $\mathrm{NA}$ & 1.2 & .001 & 1.0 & .601 \\
\hline $\mathrm{K}$ Karar & ND & $\mathrm{NI}$ & $\mathrm{ND}$ & $\mathrm{ND}$ & $4($ added) & ND & ND & NI) & ND \\
\hline $\begin{array}{l}\text { Major anions } \\
\mathrm{Cl}\end{array}$ & $\mathrm{mg} / \mathrm{L}$ & $\mathrm{mg} / \mathrm{L}$ & $\mathrm{mg} / \mathrm{L}$ & $\mathrm{mg} / \mathrm{L}$ & $\mathrm{mg} / \mathrm{L}$ (added) & $\mathrm{NI}$ & NI) & NI- & \\
\hline $\mathrm{SO}_{4}$ & 3.2 & $\begin{array}{l}19 \\
58\end{array}$ & $27^{7.6}$ & $\begin{array}{l}130 \\
210\end{array}$ & $\begin{array}{l}18 \\
14.5\end{array}$ & $\begin{array}{l}\mathrm{ND} \\
\mathrm{ND}\end{array}$ & $\begin{array}{l}\mathrm{ND} \\
\mathrm{ND}\end{array}$ & $\begin{array}{l}\mathrm{ND} \\
\mathrm{NI}\end{array}$ & $\begin{array}{l}\mathrm{ND} \\
\mathrm{ND}\end{array}$ \\
\hline $\mathrm{F}-$ & .2 & .8 & .5 & 2.5 & $\mathrm{NA}$ & ND & ND & NI) & $\mathrm{ND}$ \\
\hline $\mathrm{NO}_{3}+\mathrm{NO}_{2}-\mathrm{N}$ & $.06 i$ & .33 & .04 & .01 & 14 & ND & ND & ND & $\mathrm{ND}$ \\
\hline $\mathrm{PO}_{4}-\mathrm{P}$ & ND & ND & $\mathrm{ND}$ & ND & 1.5 & ND & $\mathrm{ND}$ & $\mathrm{ND}$ & ND \\
\hline Trace metals & $\mu \mathrm{g} / \mathrm{L}$ & $\mu \mathrm{g} / \mathrm{L}$ & $\mu \mathrm{g} / \mathrm{L}$ & $\mu \mathrm{g} / \mathrm{L}$ & $\mu \mathrm{g} / \mathrm{L}$ (added) & $\mu \mathrm{g} / \mathrm{L}$ & $\mu \mathrm{g} / \mathrm{L}$ & $\mu \mathrm{g} / \mathrm{L}$ & $\mu \mathrm{g} / \mathrm{L}$ \\
\hline $\mathrm{Mn}$ & $\begin{aligned} 2 \\
-3\end{aligned}$ & 2 & 1 & $<1$ & 1.3 & 4,910 & 6.14 & 3.170 & 2.77 \\
\hline Zn & $<3$ & $<3$ & $<3$ & $<3$ & 2.6 & 303 & .38 & 18 & .016 \\
\hline $\mathrm{Li}$ & $<4$ & 5 & 5 & 11 & $\mathrm{NA}$ & 176 & .22 & 246 & .21 \\
\hline $\mathrm{Cu}$ & $<10$ & $<10$ & $<10$ & $<10$ & .06 & 103 & .13 & 30 & .026 \\
\hline $\mathrm{Ba}$ & 7 & 10 & 20 & 10 & $\mathrm{NA}$ & 87 & .11 & 80 & . 170 \\
\hline Fe & $<10$ & $<10$ & $<10$ & $<10$ & 56 & 65 & .081 & 24 & .021 \\
\hline $\mathrm{Co}$ & $<3$ & $<3$ & $<3$ & $<3$ & .15 & 29 & .036 & $\begin{array}{r}4 \\
4\end{array}$ & .003 \\
\hline Cd & $<1$ & $<1$ & $<2$ & $<1$ & $\mathrm{NA}$ & 17 & .020 & 9 & .008 \\
\hline \multirow{3}{*}{ Dissolved organic carbon } & $<10$ & $<10$ & $<10$ & $<10$ & .14 & 8 & .010 & 31 & .027 \\
\hline & $\mathrm{mgC} / \mathrm{L}$ & $\mathrm{mgC} / \mathrm{L}$ & $\mathrm{mgC} / \mathrm{L}$ & $\mathrm{mgC} / \mathrm{L}$ & $\mathrm{mgC/L}$ (added) & $\mathrm{mgC/L}$ & $\mathrm{mgC} / \mathrm{g}$ & $\operatorname{mgc} / L$ & $\mathrm{mgCl} / \mathrm{g}$ \\
\hline & .8 & 5.7 & 4.3 & 13.2 & $1=$ & 69 & .086 & 52 & .045 \\
\hline $\mathrm{pH}$ & ND & 7.5 & 6.5 & 8.7 & 8.0 & 7.1 & ---- & 7.4 & $\ldots$ \\
\hline Alkalinity in milliequivalents $/ \mathrm{L}$ & .3 & 4.19 & 2.8 & 16.8 & .3 & ---- & --- & ---- & ---- \\
\hline Chlorophyll a in $\mu \mathrm{g} / \mathrm{L}$ & 31 & 1.9 & 78.6 & 9.5 &.--- & ---- & ---- & $\cdots$ & --- \\
\hline
\end{tabular}

Location of lakes shown in figure 1; lakes were sampled on July 18, 1980.

${ }^{2} 1 \mathrm{mgC} / \mathrm{L}$ obtained by adding Biscayne fulvic acid (Thurman and Malcolm, written communication, 1980). 
the Richland, Wash., area was lethal to Anabaena flos-aquae at dilutions of up to 1:100. Even at weaker dilutions of up to $1: 500$, the ash leachate caused abnormal morphologies in the algal cells. These biological effects are particulary startling, because the noted laboratory dilutions approximate natural levels of chemical constituents that could be leached from volcanic ash; for example, a 1:250 dilution corresponds to one centimeter of ash falling into a lake with a mixing depth of 2.5 meters.

The objectives of the present study are to:(1) determine whether trace elements, organic compounds, or both, are the toxic components in the leachate from volcanic ash deposited at Richland; (2) isolate and identify the trace metals or organic compounds causing the toxicity; and (3) determine if leachate from volcanic ash deposited near Moses Lake, Wash., is also toxic to blue-green algae. The Moses Lake region in central Washington has many lakes and received one of the thickest ash deposits (fig. 1). The hypothesis that the observed areal variations in organic and inorganic composition of the ash (Leenheer, oral communication, 1980) would result in corresponding variations in toxicity of leachate from volcanic ash was also tested.

To aid the reader, a glossary of technical terms is included at the end of this report.

\section{METHODS}

BACKGROUND

To assess the effects of the Mount St. Helens ash on blue-green algal populations in lakes, bioassay experiments were conducted with Anabaena flosaquae. The general approach in bioassay work is to study the interactions between organisms and their environment under known, controlled laboratory conditions where results can be more readily interpreted than under complex field conditions. The controlled conditions in the present study consisted of constant light and temperature, and a culture medium prepared from laboratory chemicals to simulate the natural aquatic environment. Several simultaneous bioassay experiments were conducted using different chemical fractions of the leachate from volcanic ash to determine the chemical characteristics of the toxic constituents. The flow chart in figure 2 shows the experimental design used in the experiments. Essentially, the experiment consisted of: (1) testing the toxicity of the unfractionated leachate; (2) passing the leachate through a cation-exchange resin; and (3) testing the toxicity of the effluent from which most trace metals had been removed; and (4) testing the toxicity of the trace metals removed from the leachate by the cation-exchange resin. The specific methodologies are described below in the following

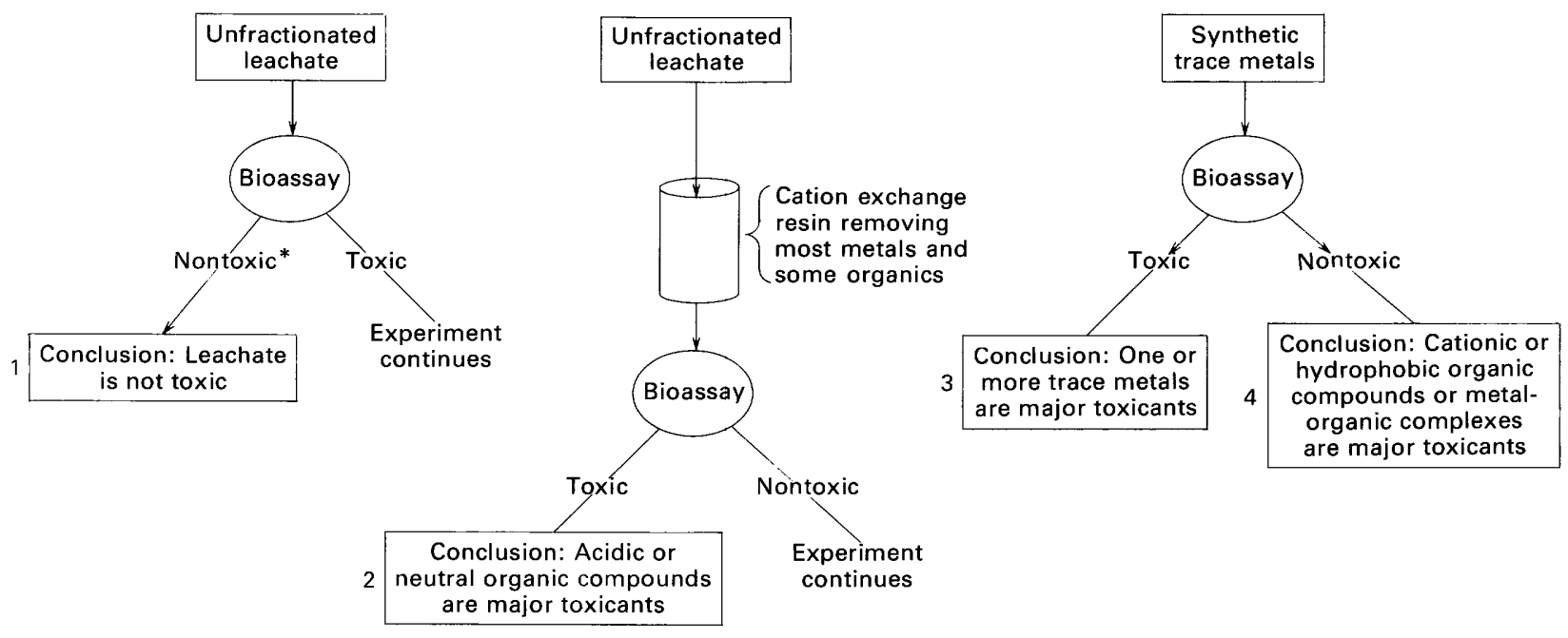

* Experiment continues to compare fractionation with toxic leachates and to determine if any fraction stimulates growth.

FIGURE 2. - Generalized flow chart showing experimental design used to determine the general character of toxicants in leachate from volcanic ash. 
sequence: (1) culture of blue-green algae; (2) leaching of volcanic ash samples; (3) fractionation of leachates; and (4) addition of leachate fractions to algal cultures.

\section{CULTURE OF ANABAENA FLOS-AQUAE}

Anabaena flos-aquae UTEX 1444 was grown in 250 milliliters $(\mathrm{ml})$ of synthetic freshwater culture medium (WC medium) in $500 \mathrm{ml}$ polycarbonate Erlenmeyer flasks at $23^{\circ} \mathrm{C}$ under continuous light. Synthetic culture medium provides more optimal conditions than most natural waters, permitting Anabaena to grow faster, and providing for more reproducible and controlled experiments. Other reasons for using synthetic culture medium are the large variations in chemistry of lake waters in the study area (table 1) and the difficulty in transporting and preserving natural waters for laboratory study. Growth was monitored by measurement of the concentration of chlorophyll $a$ in the cultures every other day and by microscopic examination of the cultures.

Increase of biomass in laboratory cultures of micro-organisms normally follows a sequence of slow growth (lag phase), rapid growth (exponential growth phase), and then no growth (stationary phase) (fig. 3). Toxicants may affect microorganisms in any growth phase; for example, the lag phase may increase in length as cells adapt to the stress, the growth rate during the exponential growth phase may decrease, or the maximum biomass reached during the stationary phase may be lowered, owing to inhibition of nutrient assimilation.

\section{LEACHING OF VOLCANIC ASH}

In the experiment with volcanic ash collected at Richland, leachate was eluted with WC medium from a column packed with 80 grams of ash and

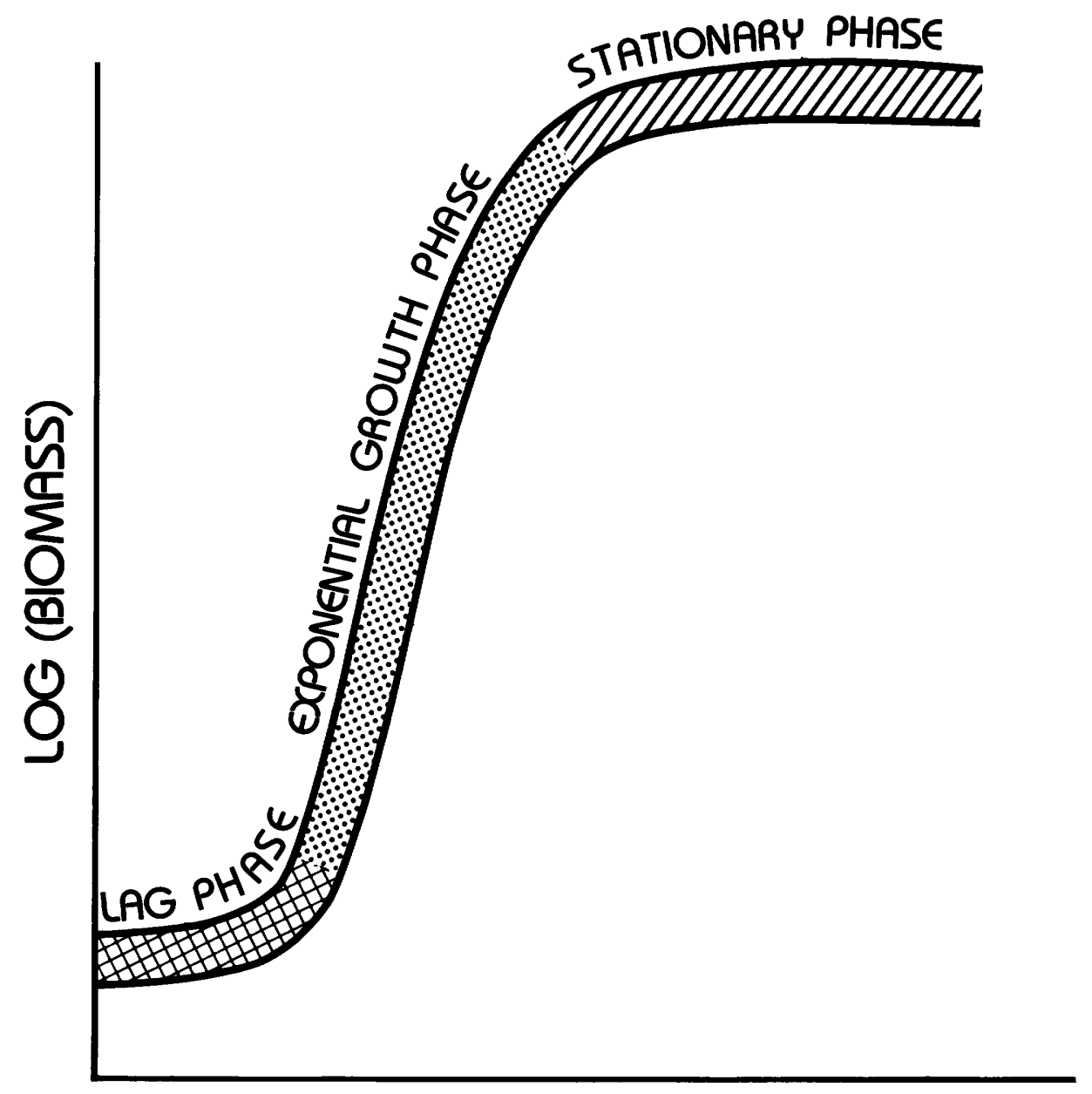

TIME

FIGURE 3. - Idealized growth curve for micro-organisms. 
saturated for 14 hours at $23^{\circ} \mathrm{C}$ with $100 \mathrm{ml}$ of WC medium (without trace metals or fulvic acid added). In the experiment with volcanic ash collected at Moses Lake, 172 grams of ash were leached with $150 \mathrm{ml}$ of WC medium for 12 hours at $23^{\circ} \mathrm{C}$ and the leachate was eluted from the column with WC medium. The amount of ash used in each experiment was governed by the amount of ash available for study. A Millipore ${ }^{1} \mathrm{HA} 0.45 \mu \mathrm{m}$ filter, previously leached in WC medium, was placed at the bottom of the column to retain particulate material. The leachates were stored in glass containers at $4^{\circ} \mathrm{C}$.

In table 1, the dissolved chemical constituents of unaltered WC medium and leachates from volcanic ash collected at Richland and Moses Lake are compared with those of four lakes in the ash fall area. The amounts of trace metals and organic material leached expressed as micrograms per gram of ash, are also shown. The analysis for major cations and trace metals was done by inductively coupled plasma emission spectroscopy and the dissolved organic carbon was determined with a Beckman 915 carbon analyzer. Several of the measured constituents $(\mathrm{Mn}, \mathrm{Cu}, \mathrm{Zn}, \mathrm{Cd}$, and organic carbon) were present in concentrations high enough to be possibly toxic to algae (see Hutchinson, 1957; Bartlett and others, 1974). Both leachates have high concentrations of $\mathrm{Cu}, \mathrm{Cd}$, and $\mathrm{Zn}$. Almost twice as much organic carbon was leached per gram of ash from the Richland sample, which is in accord with the trend reported by Leenheer (see page F1) toward highest organic contents in samples from the periphery of the ash fall area.

\section{FRACTIONATION OF LEACHATE FROM VOLCANIC' ASH}

In order to remove cationic trace metals and organic compounds, both the volcanic ash from leachates collected at Richland and Moses Lake were passed through a $30 \mathrm{ml}$ column of sodiumsaturated cation-exchange resin previously extracted with methanol. Owing to the different amounts of leachate available from the previous step, different volumes were fractionated for the Richland and Moses Lake samples.

A $25 \mathrm{ml}$ sample of the leachate from the ash collected at Richland was applied to the column and $50 \mathrm{ml}$ of leachate and distilled water was eluted with distilled water. Only 67 percent of the organic

\footnotetext{
1 The use of brand names in this report is for identification purposes only and does not imply endorsement by the U.S. Geological Survey.
}

carbon in the leachate was recovered in the $50 \mathrm{ml}$. Another $50 \mathrm{ml}$ of distilled water was passed through the column bringing the total recovery of dissolved organic carbon to 83 percent. These two $50 \mathrm{ml}$ effluent fractions were combined resulting in a fourfold dilution of the leachate. As shown in table 2, most of the trace metals were removed by the cation-exchange resin.

A $50 \mathrm{ml}$ sample of the leachate from ash collected at Moses Lake was applied to an identical column and eluted with distilled water and $100 \mathrm{ml}$ of column effluent was collected. The recovery of dissolved organic carbon in the effluent was 93 percent, much higher than with the Richland leachate (table 2). Most of the trace metals in the Moses Lake leachate were retained by the cationexchange resin.

\section{ADDITION OF LEACHATE FRACTIONS TO ALGAL CULTURES}

The leachate fractions were filter sterilized and added to duplicate flasks of culture medium before inoculation with Anabaena flos-aquae. Because the ash leachate from ash collected at Moses Lake had a lower concentration of dissolved organic carbon, the amounts of leachate added were scaled to approximate the concentrations of dissolved organic carbon in leachate from ash collected at Richland that were toxic in the preliminary experiment. In the two main experiments, a concentration of 2 milligrams dissolved organic carbon per liter (mg $\mathrm{C} / \mathrm{L}$ ) was used to correspond to the 1:50 dilution that was completely inhibitory, and a concentration of $0.2 \mathrm{mg} \mathrm{C} / \mathrm{L}$ was used to correspond to the 1:500 dilution that caused abnormal cell morphologies, but did not inhibit growth.

Table 3 presents the concentrations of trace metals and dissolved organic carbon obtained in the culture media by adding different volumes of unmodified leachate from volcanic ash, cationexchanged leachate, and synthetic trace metals. The synthetic trace-metal solutions were formulated to reproduce concentrations of trace metals in the leachates which might be toxic to algae at a 1:100 dilution. Manganese was highest in concentration among the trace metals in both leachates. However, even at the 1:25 dilution, the concentrations of manganese approximated those in natural waters of the affected area (compare table 3 to table 1 ). 
TABLE 2. - Dissolved constituents in leachate from volcanic ash after passing through cation-exchange resin column.

\begin{tabular}{|c|c|c|c|c|}
\hline & \multicolumn{4}{|c|}{ Leachate from Mount St. Helens volcanic ash collected at Richland and Moses Lake } \\
\hline & \multicolumn{2}{|c|}{ Richland' ${ }^{1}$} & \multicolumn{2}{|c|}{$\begin{array}{c}\text { Moses Lake"2 } \\
\end{array}$} \\
\hline $\mathrm{pH}$ & \multicolumn{2}{|c|}{7.0} & \multicolumn{2}{|c|}{6.2} \\
\hline Major cations & $\begin{array}{l}\text { Concentration } \\
\text { in } \mathrm{mg} / \mathrm{L}\end{array}$ & $\begin{array}{c}\text { Percent removed } \\
\text { by exchange column }\end{array}$ & $\begin{array}{l}\text { Concentration } \\
\text { in } \mathrm{mg} / \mathrm{L}\end{array}$ & $\begin{array}{c}\text { Percent removed } \\
\text { by exchange column }\end{array}$ \\
\hline $\mathrm{Na}$ & 150 & 300 (increase) & 352 & 172 (increase) \\
\hline $\mathrm{Ca}$ & .04 & 99 & .01 & 100 \\
\hline $\mathrm{Mg}$ _-_-- & $<.04$ & 100 & $<.04$ & 100 \\
\hline $\mathrm{Sr}$ & .6 & 100 & $<.04$ & 100 \\
\hline Trace metals & $\mu \mathrm{g} / \mathrm{L}$ & Percent removal & $\mu \mathrm{g} / \mathrm{L}$ & Percent removal \\
\hline $\mathrm{Mn}$ & $<1$ & 100 & $<1$ & 100 \\
\hline $\mathrm{Zn}$ & 5.9 & 92 & .5 & 94 \\
\hline 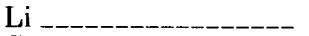 & $<4$ & 100 & $<4$ & 100 \\
\hline $\mathrm{Cu}$ & $<10$ & 100 & 1.9 & 87 \\
\hline $\mathrm{Ba}$ & 2.3 & 89 & 2.6 & 93 \\
\hline $\mathrm{Fe}$ & $<10$ & 100 & $<10$ & 100 \\
\hline Co & $<3$ & 100 & $<3$ & 100 \\
\hline $\mathrm{Cd}$ & 1.3 & 69 & .1 & 98 \\
\hline Mo _-_---_----_------ & $<10$ & 100 & $<10$ & 100 \\
\hline \multicolumn{5}{|l|}{ Dissolved organic } \\
\hline carbon in & $14.3 \mathrm{mgC} / \mathrm{L}$ & 17 & $24.3 \mu \mathrm{g} / \mathrm{L}$ & 6.5 \\
\hline
\end{tabular}

\section{RESULTS}

\section{LEACHATE FROM VOLCANIC ASH COLLECTED AT RICHLAND}

Figure 4 shows the growth curves for the experiment with leachate from volcanic ash collected at Richland. The graphs show similar growth rates for the control, cation-exchanged leachate, and synthetic trace metal cultures $(0.62,0.64$, and 0.58 day $^{-1}$, table 4). As in the preliminary experiment, the unfractionated leachate had a lethal effect on Anabaena flos-aquae at a concentration of $2 \mathrm{mg}$ $\mathrm{C} / \mathrm{L}$ of dissolved organic carbon (see table 3 ). The cultures exposed to the unfractionated leachate at a concentration of $0.27 \mathrm{mgC} / \mathrm{L}$ had a 7-day period of no net growth (lag phase), prior to an exponential growth phase with replicate growth rates of 0.51 and $0.69 \mathrm{day}^{-1}$. In comparison, a 2-day lag phase had been observed at a concentration of 0.20 $\mathrm{mgC} / \mathrm{L}$ of leachate $(1: 500$ dilution) in the preliminary experiment.

The results of this experiment corresponds to the third possibility depicted in figure 2, wherein the leachate is toxic, but the cation-exchanged leachate and the synthetic trace metals are not. The most likely conclusion is that the toxicants are part of the 17 percent of organic carbon that was retained by the cation-exchange column. Several types of organic compounds could be retained: (1) cationic-organic compounds such as amines; (2) strongly hydrophobic (sparingly soluble) organic compounds such as phenols that interact with and are retained by the resin; or (3) metal-organic complexes that are retained by interaction of the metal with the cation-exchange resin. Further experiments are planned to distinguish between these possible types of organic compounds and to obtain a sufficiently large sample of toxicant for more detailed characterization.

Photomicrographs (fig. 5) show Anabaena flosaquae filaments from the experiments with leachate from volcanic ash collected at Richland. Filaments from the cultures with cation-exchanged leachate and synthetic trace metals were similar in appearance to those in the control cultures. In the cultures with the higher concentration of unfractionated leachate, where no growth occurred, only short filaments ( $<5$ cells/chain) having an aberrated morphology were observed. In the cultures with the lower concentration of unfractionated leachate, (that grew after a 7-day lag phase), the filaments were longer ( $>20$ cells/chain), but still had an aberrated morphology. These abnormal cells were also observed in the cultures exposed to unfractionated leachate from volcanic ash collected at Richland in the preliminary experiment; they are characterized by greater width in the direction perpendicular to the filament and by a grainier appearance than normal cells. Heterocysts - the enlarged cells where nitrogen fixation 


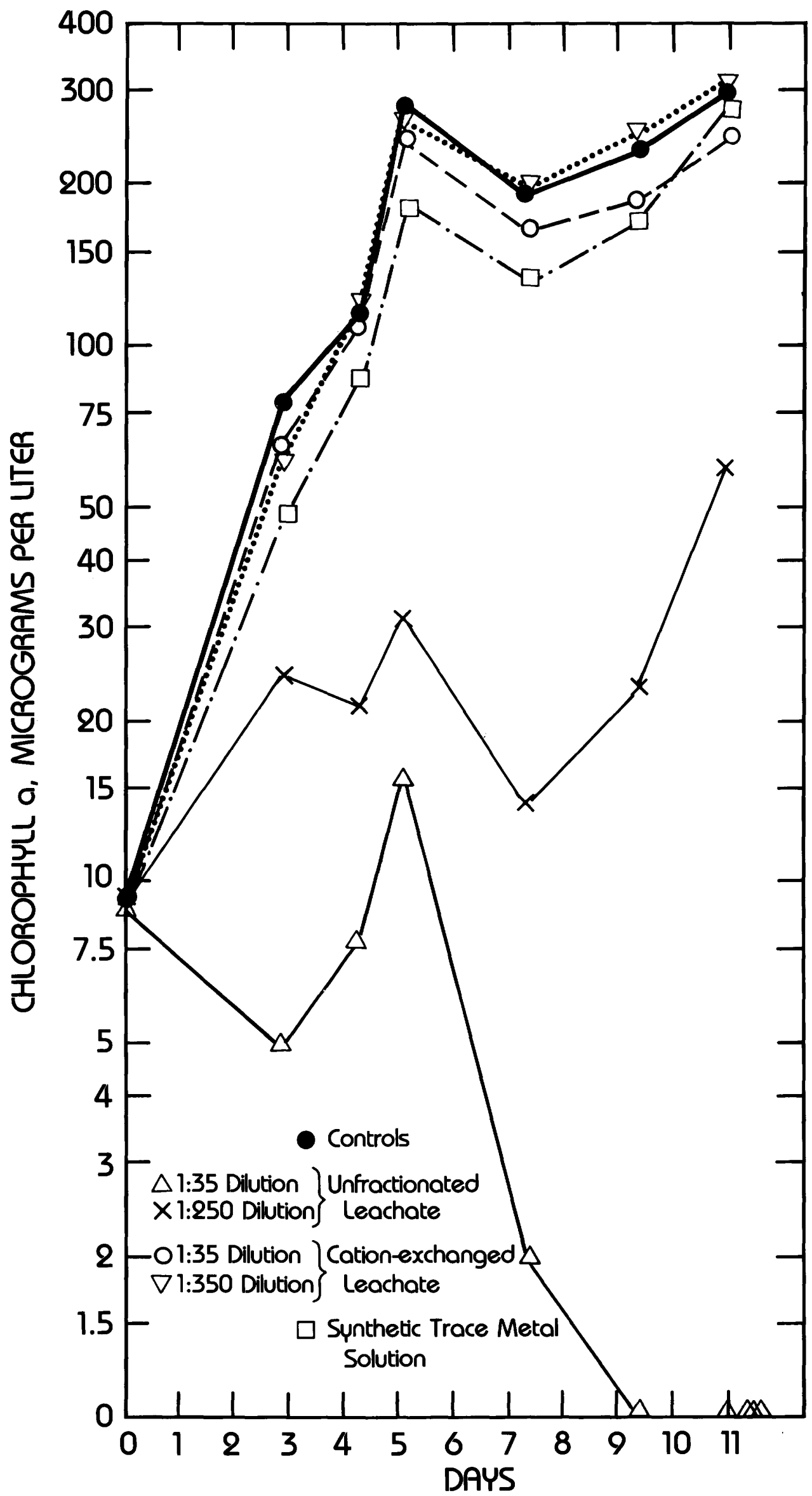

Figure 4. - Growth of Anabaena flos-aquae exposed to different fractions of leachate from volcanic ash collected at Richland. 
TABLE 3.-Concentration of dissolved organic carbon and trace metals in cultures used for bioassay experiments with Anabaena flos-aquae.

[NA not added, ND not detected]

\begin{tabular}{|c|c|c|c|c|c|c|c|c|c|c|}
\hline \multirow{4}{*}{$\begin{array}{l}\text { Parameter } \\
\text { Dilution } \\
\end{array}$} & \multicolumn{10}{|c|}{ Leachate from Mount St. Helens volcanic ash collected at } \\
\hline & \multirow{2}{*}{\multicolumn{2}{|c|}{$\begin{array}{l}\text { Concentration in culture medium } \\
\text { with unfractionated leachate } \\
\text { added' }\end{array}$}} & \multicolumn{3}{|c|}{ Richland } & \multicolumn{5}{|c|}{ Moses Lake } \\
\hline & & & $\begin{array}{l}\text { Concentratior } \\
\text { with catio } \\
\text { added }^{2}\end{array}$ & $\begin{array}{l}\text { medium } \\
\text { d leachate }\end{array}$ & \multirow[t]{2}{*}{$\begin{array}{l}\text { Concentration in } \\
\text { culture } \\
\text { medium with } \\
\text { synthetic } \\
\text { metal solution } \\
\text { added } \\
\end{array}$} & \multicolumn{2}{|c|}{$\begin{array}{l}\text { Concentration in culture medium } \\
\text { with unfractionated leachate } \\
\text { added }\end{array}$} & \multicolumn{2}{|c|}{$\begin{array}{l}\text { Concentration in culture medium } \\
\text { with cation-exchanged leachate } \\
\text { added }^{4}\end{array}$} & \multirow[t]{2}{*}{$\begin{array}{l}\text { Concentration in } \\
\text { culture medium } \\
\text { with synthetic } \\
\text { metal solution } \\
\text { added } \\
\end{array}$} \\
\hline & $1: 35$ & $1: 250$ & $1: 35$ & $1: 350$ & & $1: 25$ & $1: 250$ & $1: 25$ & $1: 250$ & \\
\hline Dissolved organic carbon $(\mathrm{mg} \mathrm{C} / \mathrm{L})$ & 2.0 & 0.27 & 1.5 & 0.15 & & 2.0 & 0.21 & 1.8 & 0.19 & \\
\hline Manganese $(\mu \mathrm{g} / \mathrm{L})$ & 139 & 19.6 & ND & ND & 150 & 122 & 12.6 & ND & ND & 122 \\
\hline $\operatorname{Zinc}(\mu \mathrm{g} / \mathrm{L})$ & 8.6 & 1.2 & 0.6 & 0.06 & 8.6 & .7 & .07 & 0.04 & 0.004 & $\mathrm{NA}$ \\
\hline Lithium $(\mu \mathrm{g} / \mathrm{L})$ & $\begin{array}{l}0.0 \\
5.0\end{array}$ & .7 & ND & ND & $\begin{array}{r}0.0 \\
10.5\end{array}$ & 9.5 & .98 & ND & ND & $\begin{array}{l}10.5 \\
9.5\end{array}$ \\
\hline Copper $(\mu \mathrm{g} / \mathrm{L})$ & $\begin{array}{l}5.0 \\
2.9\end{array}$ & .4 & ND & $\mathrm{ND}$ & $\begin{array}{r}10.3 \\
3.1\end{array}$ & $\begin{array}{l}9.0 \\
1.1\end{array}$ & .12 & .14 & .02 & $\begin{array}{l}9.0 \\
1.1\end{array}$ \\
\hline Barium $(\mu \mathrm{g} / \mathrm{L})$ & 2.5 & .4 & .2 & .03 & $\mathrm{NA}$ & 3.1 & .32 & .19 & .02 & $\mathrm{NA}$ \\
\hline $\operatorname{Iron}(\mu \mathrm{g} / \mathrm{L})$ & 1.8 & .3 & ND & ND & $\mathrm{NA}$ & $\begin{array}{r}0.1 \\
.9\end{array}$ & .10 & ND & ND & NA \\
\hline Cobalt $(\mu \mathrm{g} / \mathrm{L})$ & .8 & .12 & ND & ND & NA & .15 & .02 & ND & ND & NA \\
\hline Cadmium $(\mu \mathrm{g} / \mathrm{L})$ & .5 & .07 & .14 & .01 & 1.1 & .3 & .04 & .01 & .001 & .3 \\
\hline Molybdenum $(\mu \mathrm{g} / \mathrm{L})$ & .23 & .03 & $\mathrm{ND}$ & ND & .57 & 1.2 & .12 & $\mathrm{ND}$ & ND & 1.2 \\
\hline
\end{tabular}

${ }^{1}$ The 1:35 dilution was obtained by adding $7.3 \mathrm{ml}$ of unfractionated leachate to $250 \mathrm{ml}$ of culture medium.

The 1:250 dilution was obtained by adding $1 \mathrm{ml}$ of unfractionated leachate to $250 \mathrm{ml}$ of culture medium.

${ }^{2}$ The 1:35 dilution was obtained by adding $29.2 \mathrm{ml}$ of cation-exchanged leachate to $250 \mathrm{ml}$ of culture medium

The 1:350 dilution was obtained by adding $2.9 \mathrm{ml}$ of cation-exchanged leachate to $250 \mathrm{ml}$ of culture medium.

${ }^{3}$ The $1: 25$ dilution was obtained by adding $10 \mathrm{ml}$ of unfractionated leachate to $250 \mathrm{ml}$ of culture medium.

The 1:250 dilution was obtained by adding $1 \mathrm{ml}$ of unfractionated leachate to $250 \mathrm{ml}$ of culture medium.

${ }^{4}$ The 1:25 dilution was obtained by adding $20 \mathrm{ml}$ of cation-exchanged leachate to $250 \mathrm{ml}$ of culture medium.

The 1:250 dilution was obtained by adding $2 \mathrm{ml}$ of cation-exchange leachate to $250 \mathrm{ml}$ of culture medium. 

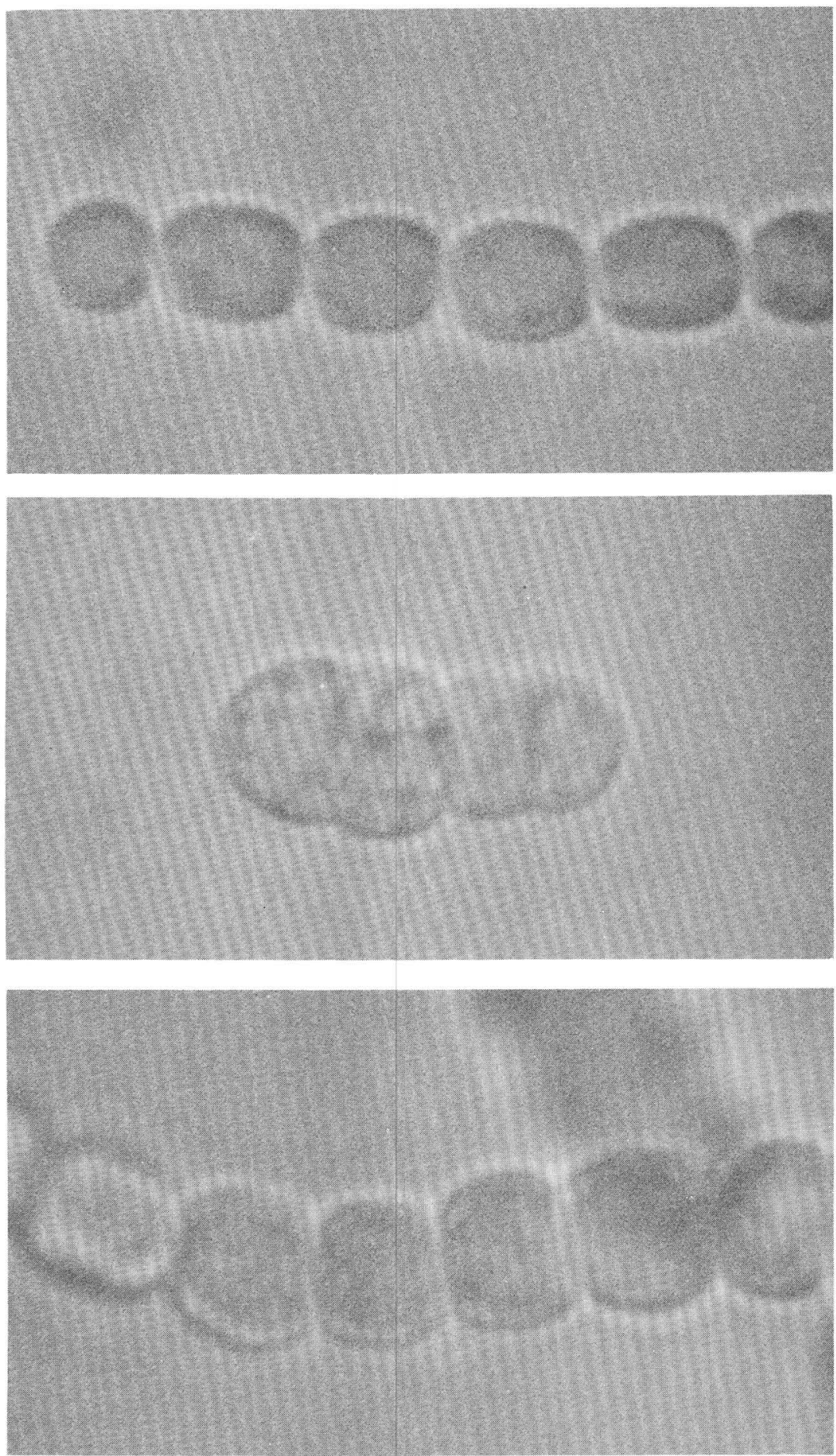

FiguRE 5. - Photomicrographs showing morphological differences between Anabaena flos-aquae grown in cultures exposed to various concentrations of unfractionated leachate from volcanic ash collected at Richland. A. Control cultures; B. Cultures exposed to a 1:35 dilution; C. Cultures exposed to a 1:250 dilution. (Enlargements of photomicrographs taken of unpreserved cultures with light microscope.) 
TABLE 4.-Growth rates of duplicate Anabaena flos-aquae cultures exposed to different fractions of leachates from volcanic ash. ${ }^{1}$

Leachate from volcanic ash collected at Richland

\begin{tabular}{|c|c|c|}
\hline \multirow[t]{2}{*}{. } & \multicolumn{2}{|c|}{$\begin{array}{l}\text { Growth rate, day }{ }^{-1} \text {, computed } \\
\text { from day } 0 \text { to day } 5.1\end{array}$} \\
\hline & Culture & $\begin{array}{l}\text { Duplicate } \\
\text { culture }\end{array}$ \\
\hline Control cultures & 0.64 & 0.64 \\
\hline Unfractionated leachate ( $1: 35$ dilution)_-_-_-- & - no growth & --- \\
\hline Unfractionated leachate (1:250 dilution) & $\quad 0.51^{2}$ & $0.69^{2}$ \\
\hline Cation-exchanged leachate (1:35 dilution) & .62 & .62 \\
\hline Cation-exchanged leachate (1:350 dilution) & .62 & .67 \\
\hline Synthetic trace metals & .58 & .58 \\
\hline
\end{tabular}

Leachate from volcanic ash collected at Moses Lake

\begin{tabular}{|c|c|c|}
\hline & \multicolumn{2}{|c|}{$\begin{array}{l}\text { Growth rate, day }{ }^{-1} \text {, computed } \\
\text { from day } 2 \text { to day } 4.4\end{array}$} \\
\hline & Culture & $\begin{array}{l}\text { Duplicate } \\
\text { culture }\end{array}$ \\
\hline Control cultures & 0.71 & 0.83 \\
\hline Unfractionated leachate (1:25 dilution) & 0.69 & 0.74 \\
\hline Unfractionated leachate (1:250 dilution) & .71 & .69 \\
\hline Cation-exchanged leachate (1:25 dilution)_-_- & .69 & .69 \\
\hline Cation-exchanged leachate (1:250 dilution) & .74 & .71 \\
\hline Synthetic trace metals & .67 & .69 \\
\hline
\end{tabular}

' See table 3 for the content of dissolved organic carbon and selected trace metals in each culture.

${ }^{2}$ Growth rate after 7 -day lag phase.

occurs in filamentous blue-green algae-were observed in all cultures, except those exposed to the unfractionated leachate from volcanic ash. Perhaps the toxicants act at the cell wall and interfere with nitrogen assimilation.

Duplicate cultures of fresh, untreated WC medium were inoculated with abnormal Anabaena flos-aquae cells from the Richland experimental cultures. The cultures inoculated with Anabaena flos-aquae cells initially exposed to the lower concentration of leachate grew within a week, whereas the cultures innoculated with cells exposed to the higher leachate concentration grew after three weeks. No abnormal cells were observed in the final cultures, indicating that the effect of the toxicants on the morphology of the blue-green algal cells is reversible.

\section{LEACHATE FROM VOLCANIC ASH COLLECTED AT MOSES LAKE}

Figure 6 presents the growth curves from the experiment in which different fractions of leachate from volcanic ash collected at Moses Lake were added to Anabaena flos-aquae cultures. None of the leachate additions had significant effects on growth or final biomass, nor caused changes in cell morphology. The data in table 4 shows no significant difference in growth rate computed from day 2 to day 4.4 among the various cultures.
The failure to observe any toxic effect of the leachate from volcanic ash collected at Moses Lake is not surprising given that (1) the toxicants in the leachate from volcanic ash collected at Richland were apparently part of the 17 percent of the dissolved organic carbon retained by the cationexchange column and (2) this fraction contributed only 7 percent of the total dissolved organic carbon to the leachate from volcanic ash collected at Moses Lake. The toxicants may not be present in the leachate or they may occur in relatively much lower concentrations.

\section{SUMMARY AND CONCLUSIONS}

The data reported here confirm that leachate from volcanic ash collected at Richland is toxic to Anabaena flos-aquae at large dilutions. In addition, the results indicate the toxic substances are probably organic compounds retained on a cationexchange resin, rather than uncomplexed trace metals such as $\mathrm{Mn}, \mathrm{Zn}, \mathrm{Cu}$, and $\mathrm{Cd}$; or anionic or hydrophillic (readily soluble) organic compounds. The toxic constituents retained on the cationexchange resin could be one or more of the following types: (1) cationic-organic compounds such as amines; (2) strongly hydrophobic (sparingly soluble) organic compounds such as phenols that interact with and are retained by the resin; or (3) metal-organic complexes which are retained by interaction of the metal with the cation-exchange resin. Further experiments are being conducted to provide more specific identification of the toxic compounds.

Results indicate that the leachate from ash collected at Moses Lake has neither an inhibitory nor stimulatory effect on the growth of Anabaena flosaquae. This finding is consistent with the contrasting results from the experiment using leachate from volcanic ash collected at Richland, because the fraction of that leachate shown to be toxic occurs at a much lower concentration in the Moses Lake sample. The toxicants found in the leachate from the volcanic ash collected at Richland may either be absent or occur in much lower, nontoxic concentrations in the leachate from ash collected at Moses Lake.

Visual observation and other data (Fruchter and others, 1980) have shown that the volcanic ash was fractionated (sorted by weight of particles) as it was carried eastward from Mount St. Helens. The lighter materials were carried farthest, and this distribution is reflected in data showing highest concentrations of dissolved organic carbon in 


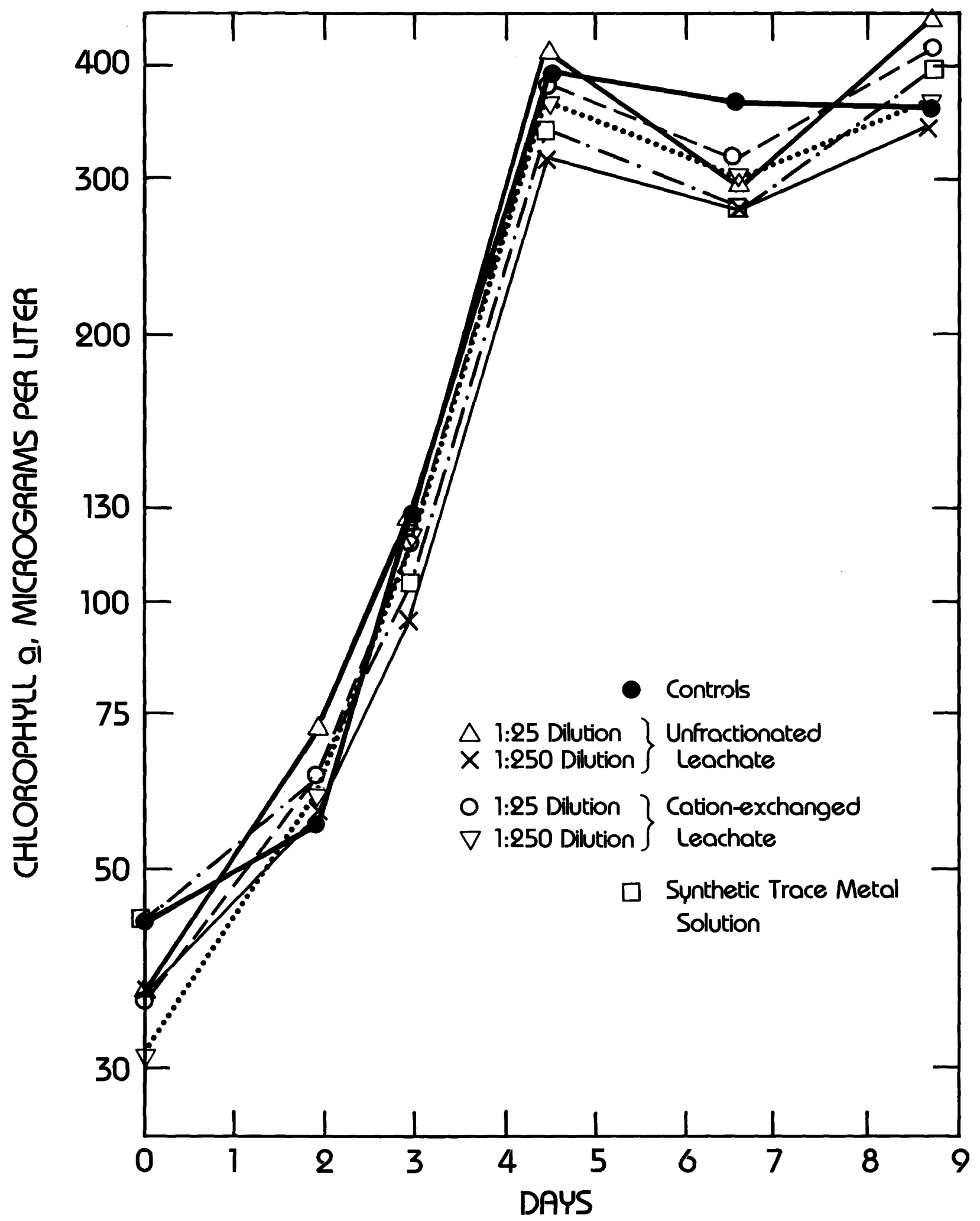

Figure 6. - Growth of Anabaena flos-aquae exposed to different fractions of leachate from volcanic ash collected at Moses Lake. 
samples from the periphery of the ash fall area (Taylor and Lichte, 1980; Pereira and others, 1980). Delineation of the geographic distribution of the toxicants is planned for future study. This information will help identify lakes and streams most likely to be affected by volcanic ash deposition. Inhibition of blue-green algal growth in Liberty Lake, Wash. (see fig. 1), which has a history of nuisance blue-green algal blooms, has already been reported (W. H. Funk, Washington State University, written communication, 1980).

The failure to observe toxicity in laboratory experiments with leachate from volcanic ash collected at Moses Lake is consistent with field observations of algal populations in several lakes from the area. Soap Lake and Lake Lenore, northwest of the town of Moses Lake, have been studied for several decades and their summer phytoplankton assemblages during 1980 were similar to those in previous years (Walker, 1975; W. T. Edmondson, University of Washington, oral communication, 1980). Moses Lake, itself, had the usual dense, blue-green algal bloom. In Warden Lake, south of the town of Moses Lake, the 1980 phytoplankton assemblage was dominated by diatoms and chysophytes, the same as reported (Dione and others, 1980) for previous years.

\section{GLOSSARY}

[Many definitions were obtained or modified from Rickert and others, 1977)

Alga, algae (n), algal (adj). Simple plants, many microscopic containing chlorophyll. Most algae are aquatic and are the primary food source in most lakes.

Algal bloom (n). A large number of particular algal species, frequently amounting to 0.5 to 1 million cells per liter of water. Sometimes defined as a readily visible, concentrated growth or aggretation of algae.

Algal filament (n). A chain of algal cells.

Amines (n). Organic compounds which are amonia derivatives $\left(\mathrm{R}-\mathrm{NH}_{2}\right)$.

Aquatic (adj). Pertaining to water; aquatic organisms such as algae or fish, live to water.

Bioassay (n). The use of living organisms to test the effects of a substance on the organism.

Biomass (n). The weight of living matter present in a unit area or volume of water at a given time.

Blue-green algae (n). A group of algae that are similar to bacteria in cell structure. Members of this group are abundant in natural waters.

Cation (n). A positively charged ion in solution.

Cation-exchange resin (n). A resin that removes cations from solution by exchange with another cation, typically $\mathrm{H}^{+}$.

Chlorophyll $\boldsymbol{a}(\mathbf{n})$. The major plant involved in photosynthesis.

Dissolved organic carbon (n). Organic carbon that passes through a $0.45 \mu \mathrm{m}$ filter.
Ecological (adj). Pertaining to the relation of organisms or groups of organisms to their environment.

Ecosystem (n). A group of interacting organisms and their physical environment.

Effluent (n). A solution that has passed through a chromatographic column.

Fulvic acid (n). A class of organic compounds of high molecular weight that accounts for 30 to 60 percent of the dissolved organic carbon in natural waters.

Growth rate (n). The rate at which organisms increase in number with time.

Inoculum (n). The material used to make an inoculation.

Leachate (n). A solution containing soluble constituents removed from ash, soil, or other natural material by percolation.

Metal-organic complex (n). Chemical association of a metal ion with an organic compound.

Morphology (n). The form and structure of an organism considered as a whole.

Nitrogen fixation (n). The process of assimilating atmospheric nitrogen to form organic nitrogen compounds.

Nutrient (n). Any chemical element, ion, or compound that is required by an organism for growth, for reproduction, or for other life processes. Trace nutrients are substances required by an organism in very small amounts.

Organic (n). Pertaining or relating to a compound containing carbon.

Organism (n). Any living entity.

pH (n). The reciprocal of the logarithm (to the base 10) of the hydrogen ion activity in water. The $\mathrm{pH}$ value of water is a measure of the degree of its acidity or alkalinity.

Phenols (n). Aromatic organic compounds having at least one hydroxyl group attached to a benzene ring.

Phytoplankton (n). The plant organisms (mainly algae) that drift passively with water currents.

Pyrolized (adj). Pertaining to the subjection of organic compounds to very high temperature.

Synthetic medium (n). A solution made from chemical reagents.

Toxic (adj), toxicity (n), toxicant (n). Having the effect of a poison.

Trace metal (n). A metal generally found in small quantities in the environment.

\section{REFERENCES}

Bartlett, Larry, Rabe, F. W., and Funk, W. H., 1974, Effects of copper, zinc, and cadmium on Selanastrum capricornutum: Water Research, v, 8, p. 179-185.

Dione, N. P., Bortleson, G. C., and Innes, J. K., 1980, Data on selected lakes in Washington: Washington State Department of Ecology, Water-Supply Bulletin 42, Part 6, 125 p.

Fruchter, J. S., and others, 1980, Mount St. Helens ash from the May 18, 1980, eruption: chemical, physical, mineralogical, and biological properties: Science, v. 209, p. 1116-1125.

Hutchison, G. E., 1957, A Treatise on Limnology, v. I. Geography, Physics, and Chemistry: New York, John Wiley and Sons, $1014 \mathrm{p}$.

McKnight, D. M., and Morel, F. M. M., 1980, Copper complexation by siderophores from filamentous blue-green algae: Limnology and Oceanography, v. 25, p. 62-71.

Pereira, W. E., Rostad, C. E., and Taylor, H. E., 1980, Mt. St. Helens, Washington, 1980 volcanic eruption: characterization of organic compounds in ash samples: Geophysical Research Letters, vol. 7., no. 11, p. 953-954. 
Rickert, D. A., Peterson, R. R., McKenzie, S. W., Hines, W. G., and Wille, S. A., 1977, Algal conditions and the potential for future algal problems in the Willamette River, Oregon, U.S. Geological Survey Circular 715-G.

Sarna-Wojicki, and others, 1980, Areal distribution, thickness, and volume of downwind ash from the May 18, 1980, eruption of Mount St. Helens: U.S. Geological Survey Open-File Report 80-1078.

Stein, J. R., 1973, Growth measurement, Chapter IV of Handbook of Phycological Methods, Culture Methods and Growth
Measurements: Cambridge, England, Cambridge University Press.

Taylor, H. E., and F. E. Lichte, 1980, Chemical composition of Mount St. Helens volcanic ash: Geophysical Research Letters, vol. 7, no. 11, p. 949-952.

Walker, K. F., 1975, The seasonal phytoplankton cycles of two saline lakes in central Washington: Limnology and Oceanography, v. 20 , p. $40-53$. 